\title{
RENEWAL OF INSUFFICIENT URBAN TEXTURES EMPHASIZING ON EMPOWERMENT APPROACH (CASE STUDY: HEJRAT STREET TO PIRNIA BRIADGE IN SHIRAZ CITY, REGION 3)
}

\author{
Mohammad Reza Hassani \\ Urban planning graduate student, , Yasooj Branch, Islamic Azad University, Yasooj, Iran
}

Alireza Abdolahzade Fard

Assistant professor of Department of Urban design, Islamic Azad University, Safashahr branch, Safashahr, Iran

\begin{abstract}
Despite many efforts and dialogues on sustainable urban development in the scientific assemblies, cities of the country encounter with increasing unsustainability for reasons such as the lack of a comprehensive urban program and policy and unsustainable strategies. One of the manifestations of this unsustainability is the spread of urban worn tissues. Shiraz city like many cities of the country has not been immune from this problem. Statistical population of this research is studied neighborhood with an area of 52.8 ha. This neighborhood is one of the worn areas of Shiraz city, which encounters with a variety of issues and problems such as erosion of residential units, abundance of abandoned and dilapidated residential units and their distribution across the tissue, unfavorable appearance of the tissue, low width of passages, compression and horizontal expansion of the tissue, shortage of welfare- services land use, existence of incompatible land uses, and centralization of low income and low-profit people, high unemployment rate and social disorders. Therefore, any attempt to eliminate erosion from the neighborhood can be an effective step towards sustainable urban development. The present research has been conducted with the aim to achieve strategies of organizing this neighborhood. Its methodology is descriptive-analytical. Information has been conducted through two ways of documentary and field (observation, interview, and questionnaire). Quantitative and qualitative models means capitations standard, closest proximity method (RN), compatibility matrix, Holdren model, Pearson correlation coefficient, and ArcGIS and SPSS software have been used for data analysis. The results achieved from this research indicate that applying three general principles of "empowerment", "urban endogenous development" and "urban land uses organization" can play an important role in the sustainability of the studied erosion tissue.
\end{abstract}

Keywords: Erosion Textures organization, sustainable urban development, empowerment, urban endogenous development, urban land uses organization

\section{PROBLEM DEFINITION}

Old and worn Textures that exist in most cities of Iran had been once secure place and environment with comfort and welfare of its residents. This Texture had met their basic needs due to its culture, nationality and technology of that era and had been with an organic order (Beigzadeh, 2000: p. 1).

The early years of the twenty-first century had been accompanied with wonderful changes in human life. These changes in the context of globalization have affected economy, culture and social relations of human life. It has revealed reflection of these relations in spatial manifestations, especially cities (Razavian, 2002, preface).

Thereby several challenges and consequences have been also created in urban Textures and elements. Old Texture of cities is of these elements, which was under important effects on its own body and performance. Nowadays, the fate of cities is moving toward disharmony with its environment and context more as possible with urbanization development and modern physical interventions. It is so 
that the contrast between old and new Textures is another form of industrialization crisis. It has disrupted continuity and possibility of relation, juxtaposition of layers and sustainable presence of new Texture beside the old Texture and has created a gap between those two. In cities with worn tissue, while the city has become empty from inside and is outwearing, its surrounding areas have been developed and are developing more and more. On the other hand, a wide range within the city has been abandoned as worn Texture and is collapsing every time more than ever. Expansion of the surrounding spaces is without formation of regional and zonal services centers. Most of service centers formed in new Textures is at the level of neighborhood centers and initial needs. Therefore, excessive pressure is created on the central infrastructures of central Textures in first chapter of research overview 3 . Density in certain hours, traffic in peak hours, pollution and expansion of service and commercial spaces in surface and edge of the main streets are of its features.

On the other hand the weakness of the theoretical principles for dealing with these Textures had been an important factor in non-realization of organization of urban worn tissues. Unlike the western countries with a strong background in the formulation of theoretical principles, no serious action has been done in formulation of urbanization theories in our country. Everything that exists is an imitative pattern of some western urbanization theories or only the method of preparing urban organization plans has been imitated without the knowledge of theoretical principles.

This vacuum is somewhat more intense about intervention and rehabilitation of urban old tissues, because it's newer in Iran and lack of specific experience of the planned intervention. So that most of worn Textures organization projects have emphasized on physical dimensions and particularly the widening of passages.

\section{RESEARCH BACKGROUND}

Sadjadi, Jila and Habibi, Behzad: Social - spatial analysis of urban worn Textures in order to rehabilitate and prevent further erosion (Case Study: Region 17 of Tehran). The first conference on urban worn tissues, sustainable development perspective: Values and challenges, correlation between social, economic and cultural status of residents (low level of literacy, economic poverty, unemployment, etc.) and erosion of Texture of Region 17 of Tehran are proved in this article.

It suggests empowerment strategy for improvement in which local groups and communities solve problems of their living space autonomously until finally, the residents themselves meet their own needs with public support and provision.

Shamaei, Ali and Ahmadpour, Ahmad: Analysis of the policies and programs of urban improvement and renovation in the country development programs, Journal of Geographical researches, Issue 48, summer 2004, and pp. 204-181.

History of urban improvement, renovation and reconstruction process has been investigated in this article by citing to the policies and programs of urban civil programs and the existing effects and evidences. The main objective of this article is to review and evaluate policies, goals and executive programs of urban civil, especially about urban old tissue. The number of managerial institutions and the absence of regular organizational structure in the planning and implementation of the affair of organization, absence of patter in organization projects and being sectional and based on taste, preparation of comprehensive and detailed projects with city peripheral development attitude, attention merely to the physical organization and neglect of social and economic dimensions of old tissues, neglect of public participation, lack of financial structure defined for organization actions, and so on have been identified of the major causes of erosion of old tissue.

So comprehensive and long-term, and completely systematic policies and organization based on the "theory of sustainable development with emphasis on urban endogenous development" in which a special attention is toward the dimensions of physical, social, economic, cultural, public participation, social justice and so on are recommended to organize old tissues. 
Meshkini, Abolfazl and Ahadnejad, Mohsen: effect of policies of geologic provision in the process of erosion spread in old Texture of the cities (sample: Region 1 of Zanjan). The first conference on urban worn tissues, sustainable development perspective, values and challenges

\section{RESEARCH QUESTIONS}

Can the use of empowerment method among the various methods of worn Textures organization realize sustainable development of worn tissues?

What is the most appropriate form of service-welfare land uses distribution in new and worn Textures of Shiraz city to organize worn Textures of this city?

\section{RESEARCH METHODOLOGY}

A: information collection method: the required information has been obtained through the following ways and according to the studied topic and provided hypotheses:

- Library method includes: the use of documents, statistics and information existing in the censuses area, Persian and Latin texts, Internet sites related to the topic, as well as pictorial documents such as ethnic and non-ethnic maps;

- Field studies includes: objective observation, interview, and questionnaire

B: information analysis method: quantitative and qualitative evaluation of land uses models (including capitations, adjacency pattern, and pattern of land uses distribution (RN)), urban development models and correlation index have been used in information analysis method. Excel 2007 software has been also used to prepare tables and diagrams related to the topic. Spss 16.0 software has been used to analyze the collected data and information. ArcGIS 9.3 software has been used to receive and process information and create analytic and synthetic maps.

\section{RESEARCH FINDINGS:}

ACHIEVEMENT OF WORN TEXTURES SUSTAINABLE DEVELOPMENT:

Subject of promoting the quality of life while considering bearing capacity of the environment and responding to the needs of the present generation without creating limitations for the facilities of future generations to meet their needs is considered in all definitions related to sustainable development. In addition, it can be said that the idea of sustainability is a concept that considers four components of environmental, social, economic and physical simultaneously.

So, a comprehensive and holistic definition is posed on urban sustainability by describing these components and considerations related to urban sustainability.

Sustainable development of urban worn Textures indices after studying and reviewing the conducted research on subjects related to sustainable development are as the following tables:

Sustainable development of urban worn Textures indices

\begin{tabular}{|c|c|c|c|}
\hline $\begin{array}{c}\text { Creating } \\
\text { sustainable } \\
\text { urban } \\
\text { development }\end{array}$ & $\begin{array}{c}\text { Urban } \\
\text { Sustainable } \\
\text { Development } \\
\text { indexes }\end{array}$ & sub-indexes & $\begin{array}{c}\text { Urban } \\
\text { Sustainable } \\
\text { Development } \\
\text { Strategies }\end{array}$ \\
\hline Social & Partnership & $\begin{array}{c}\text { Inclusive participant attraction of citizens } \\
\text { in running local properties } \\
\text { Public participation in the preparation and } \\
\text { implementation of urban plans }\end{array}$ & $\begin{array}{c}\text { Social } \\
\text { empowerment }\end{array}$ \\
\hline
\end{tabular}




\begin{tabular}{|c|c|c|}
\hline & $\begin{array}{l}\text { Equal opportunities for all individuals in } \\
\text { decisions that affect their lives as well. } \\
\text { Welcoming and support the presence of } \\
\text { non-governmental organization }\end{array}$ & \\
\hline $\begin{array}{l}\text { Education } \\
\text { and } \\
\text { informing }\end{array}$ & $\begin{array}{c}\text { Attention to public education } \\
\text { Providing occupational education and } \\
\text { public education to help the workforce to } \\
\text { the future needs } \\
\text { Adequate access to public information } \\
\text { Raising awareness of the living } \\
\text { environment and protection of all it }\end{array}$ & $\begin{array}{c}\text { Social } \\
\text { empowerment }\end{array}$ \\
\hline $\begin{array}{l}\text { Reducing } \\
\text { social } \\
\text { problems }\end{array}$ & $\begin{array}{l}\text { Keep the place free from crime and } \\
\text { delinquency } \\
\text { Social security promotion }\end{array}$ & $\begin{array}{c}\text { Social } \\
\text { empowerment }\end{array}$ \\
\hline $\begin{array}{l}\text { Sanitation } \\
\text { and Health }\end{array}$ & Health promotion of residence & $\begin{array}{c}\text { Social } \\
\text { empowerment }\end{array}$ \\
\hline $\begin{array}{l}\text { Sense of } \\
\text { belonging }\end{array}$ & $\begin{array}{l}\text { Establishment of the emotional bond } \\
\text { between people and neighborhood }\end{array}$ & $\begin{array}{c}\text { Social } \\
\text { empowerment }\end{array}$ \\
\hline $\begin{array}{l}\text { Social } \\
\text { welfare }\end{array}$ & $\begin{array}{l}\text { Population stabilization of the old town } \\
\text { and preventing their migration to the new } \\
\text { urban tissues } \\
\text { Improve the quality of life level of } \\
\text { residents }\end{array}$ & $\begin{array}{c}\text { Endogenous } \\
\text { development } \\
\text { of urban and } \\
\text { social } \\
\text { empowerment }\end{array}$ \\
\hline
\end{tabular}

\section{Continued Table: Sustainable development of urban worn Textures indices}

\begin{tabular}{|c|c|c|c|}
\hline $\begin{array}{c}\text { Creating } \\
\text { sustainable } \\
\text { urban } \\
\text { development }\end{array}$ & $\begin{array}{c}\text { Urban } \\
\text { Sustainable } \\
\text { Development } \\
\text { indexes }\end{array}$ & Sub-indexes & $\begin{array}{c}\text { Urban } \\
\text { Sustainable } \\
\text { Development } \\
\text { Strategies }\end{array}$ \\
\hline Economic & $\begin{array}{c}\text { economic } \\
\text { sustainable } \\
\text { and dynamism }\end{array}$ & $\begin{array}{l}\text { Creating sustainable and various economic } \\
\text { base } \\
\text { Attracting investments in the local economy } \\
\text { Rising return on investment in the } \\
\text { neighborhood } \\
\text { Enhancing competitiveness of adjacency in } \\
\text { attracting investments to deal with the rest } \\
\text { of the city } \\
\text { Enhance the value of the properties (land }\end{array}$ & $\begin{array}{c}\text { Economic } \\
\text { empowerment } \\
\text { and } \\
\text { development of } \\
\text { urban } \\
\text { endogenous }\end{array}$ \\
\hline
\end{tabular}




\begin{tabular}{|c|c|c|}
\hline & and housing) in the neighborhood & \\
\hline $\begin{array}{l}\text { Raising the } \\
\text { level of } \\
\text { employment } \\
\text { and income }\end{array}$ & $\begin{array}{l}\text { Raising the employment rate and of revenue } \\
\text { adjacency residents } \\
\text { Reducing the unemployment rate } \\
\text { Raising the stable financial sources } \\
\text { Poverty Reduction } \\
\text { Raising the purchasing power of people }\end{array}$ & $\begin{array}{c}\text { Economic } \\
\text { empowerment } \\
\text { and } \\
\text { development of } \\
\text { urban } \\
\text { endogenous }\end{array}$ \\
\hline Efficiency & $\begin{array}{l}\text { Using vacant lands and abandoned buildings } \\
\text { preventing erosion of buildings as much as } \\
\text { possible } \\
\text { Spatial recycling and utilization of } \\
\text { dilapidated urban spaces } \\
\text { Encourage to integrate the fine grained parts } \\
\text { A moderate increase in density }\end{array}$ & $\begin{array}{c}\text { Endogenous } \\
\text { development of } \\
\text { urban }\end{array}$ \\
\hline $\begin{array}{c}\text { Permeability } \\
\text { and promoting } \\
\text { accesses }\end{array}$ & $\begin{array}{c}\text { Widening of the passages } \\
\text { Ease of movement with the use of new } \\
\text { means of transport } \\
\text { Immunization of streets and arteries } \\
\text { Observing the hierarchy of roads and } \\
\text { communication network } \\
\text { Proper design of the arteries, in reducing } \\
\text { traffic and transportation, reducing energy } \\
\text { consumption and air pollution. } \\
\text { Encourage people to walking } \\
\text { Increase in public transport }\end{array}$ & $\begin{array}{l}\text { Endogenous } \\
\text { development of } \\
\text { urban, mixed } \\
\text { land use and } \\
\text { physical } \\
\text { empowerment }\end{array}$ \\
\hline $\begin{array}{l}\text { Composition } \\
\text { and diversity } \\
\text { of land use }\end{array}$ & $\begin{array}{c}\text { Mixing residential users and services - } \\
\text { welfare in order to enhance public welfare } \\
\text { Creating new occupational opportunities } \\
\text { near living place } \\
\text { Regular distribution of land use and } \\
\text { preventing their polarization } \\
\text { Removal of incompatible land uses and } \\
\text { convert them into the required land use of } \\
\text { neighborhood } \\
\text { Creating adequate service levels } \\
\text { Urban user reorganization fit with capacity }\end{array}$ & $\begin{array}{l}\text { Land uses } \\
\text { organization } \\
\text { with an } \\
\text { emphasis on } \\
\text { diversity of land } \\
\text { uses, } \\
\text { eliminating } \\
\text { incompatible } \\
\text { land uses and } \\
\text { regularly } \\
\text { distribution of } \\
\text { them and } \\
\text { endogenous } \\
\text { development of }\end{array}$ \\
\hline
\end{tabular}




\begin{tabular}{|l|l|c|c|}
\hline & $\begin{array}{c}\text { of the environment } \\
\text { A ban on the development of land uses that } \\
\text { leads to pollution such as noise and visual } \\
\text { disturbance or loss of recreational } \\
\text { opportunities. }\end{array}$ & urban \\
\cline { 2 - 4 } & & \\
\hline
\end{tabular}

Continued Table: Sustainable development of urban worn Textures indices

\begin{tabular}{|c|c|c|c|}
\hline $\begin{array}{c}\text { Creating } \\
\text { sustainable } \\
\text { urban } \\
\text { development }\end{array}$ & $\begin{array}{c}\text { Urban } \\
\text { Sustainable } \\
\text { Development } \\
\text { indexes }\end{array}$ & Sub-indexes & $\begin{array}{c}\text { Urban } \\
\text { Sustainable } \\
\text { Development } \\
\text { Strategies }\end{array}$ \\
\hline & $\begin{array}{c}\text { Quality } \\
\text { Improvement }\end{array}$ & $\begin{array}{c}\text { Creating appropriate urban infrastructure } \\
\text { Being physical manifestations pleasant and } \\
\text { visual for people } \\
\text { Attention to human scale in designing spaces } \\
\text { Preservation of natural landscapes in the } \\
\text { neighborhood } \\
\text { Anabasis load and maintain historical buildings } \\
\text { Preservation and promotion of public spaces and } \\
\text { lack of historical curtailment } \\
\text { Increase the attractiveness and readability of } \\
\text { neighborhood }\end{array}$ & $\begin{array}{c}\text { Physical } \\
\text { empowerment }\end{array}$ \\
\hline environmental & $\begin{array}{l}\text { Preservation } \\
\text { and } \\
\text { promotion of } \\
\text { natural } \\
\text { ecosystems }\end{array}$ & $\begin{array}{l}\text { Reduction of air pollutants, audio and sewage } \\
\text { Protection of water resources, land, energy and } \\
\text { reduce consumption of non-renewable resources } \\
\text { and preventing pollution of them } \\
\text { Maintain and enhance levels of local green } \\
\text { spaces } \\
\text { Energy regulation for buildings } \\
\text { Flow cyclical material recycling infrastructure in } \\
\text { local ecosystems } \\
\text { Estimating basic human needs and access to } \\
\text { healthy air, water and nutrition }\end{array}$ & $\begin{array}{c}\text { Environmental } \\
\text { empowerment } \\
\text { and } \\
\text { organization } \\
\text { of Texture } \\
\text { Land uses }\end{array}$ \\
\hline & $\begin{array}{l}\text { Safety and } \\
\text { Security }\end{array}$ & $\begin{array}{c}* \text { The security of adjacency from natural } \\
\text { disasters (such as earthquakes) and abnormal } \\
\text { events }\end{array}$ & $\begin{array}{l}\text { Environmental } \\
\text { Empowerment }\end{array}$ \\
\hline
\end{tabular}




\section{Source: Author}

(Swot) Information Measurement Table

\begin{tabular}{|c|c|c|c|c|}
\hline threats & Opportunities & Weakness points & Strength points & Tendency \\
\hline $\begin{array}{l}\text { * Creating Pollution } \\
\text { and unpleasant smell } \\
\text { by vegetable oil } \\
\text { factory in Shiraz } \\
\text { * lack of observing } \\
\text { principles and } \\
\text { Architecture and } \\
\text { Urbanism Criteria } \\
\text { Legal problems of } \\
\text { residents and } \\
\text { businesses with the } \\
\text { municipality } \\
\text { * Wrapping } \\
\text { earthquake-prone } \\
\text { range in the town } \\
\text { * creating } \\
\text { environmental } \\
\text { pollutions by } \\
\text { terminals of Shahid } \\
\text { Karandish } \\
\text { * Development of } \\
\text { repair shops, vehicle } \\
\text { and workshop } \\
\text { service } \\
\text { - The presence of } \\
\text { open spaces with } \\
\text { cozy and defenseless } \\
\text { corners } \\
\text { *Excavation and } \\
\text { widespread } \\
\text { destruction resulting } \\
\text { from the } \\
\text { construction of } \\
\text { pathways and glazed } \\
\text { car access, } \\
\text { especially in South } \\
\text { Beach }\end{array}$ & $\begin{array}{l}\text { * Special position } \\
\text { of the area } \\
\text { beacause of } \\
\text { existing Modarres } \\
\text { ceremonial axis } \\
\text { and historical } \\
\text { - cultural axis of } \\
\text { Hafez } \\
\text { * Special position } \\
\text { of area because of } \\
\text { its adjacency to } \\
\text { the historical } \\
\text { cultural area range } \\
\text { and its index } \\
\text { elements } \\
\text { * Special position } \\
\text { of area due to its } \\
\text { adjacency the } \\
\text { elements such as } \\
\text { the tomb of Hafez } \\
\text { Darvazeh Qoran, } \\
\text { National Garden, } \\
\text { Jahan nama garden } \\
\text { and ... } \\
\text { *existing Hafez } \\
\text { axis as the } \\
\text { aforementioned } \\
\text { connecting } \\
\text { elements with the } \\
\text { historic texture of } \\
\text { the town } \\
\text { * existing dry river } \\
\text { as a binding factor } \\
\text { with northern and } \\
\text { eastern hights of } \\
\text { the town } \\
\text { * existing major } \\
\text { open spaces, } \\
\text { especially in the } \\
\text { vicinity of the river } \\
\text { and Creating } \\
\text { suitable potential }\end{array}$ & $\begin{array}{l}\text { * Creating Pollution } \\
\text { and unpleasant } \\
\text { smell of the dry } \\
\text { river } \\
\text { * creating pollution, } \\
\text { annoyance by units } \\
\text { of automotive } \\
\text { service and repair } \\
\text { shops } \\
\text { * creating pollution, } \\
\text { unpleasant smell by } \\
\text { refrigerating room } \\
\text { and Alavi Hospital } \\
\text { *buses } \\
\text { accumulation bus } \\
\text { stages and creating } \\
\text { air pollution and } \\
\text { audio pollution } \\
\text { * Air creating } \\
\text { pollution, audio and } \\
\text { congestion by traffic } \\
\text { directorate } \\
\text { * Lack of sufficient } \\
\text { green space in the } \\
\text { area } \\
\text { * Lack of } \\
\text { elementary and } \\
\text { secondary schools, } \\
\text { and appropriate with } \\
\text { resident population } \\
\text { sanitation systems } \\
\text { * Lack of } \\
\text { appropriate } \\
\text { recreational places } \\
\text { *Lack of adjacency } \\
\text { services } \\
\text { Commercial units } \\
\text { ande }\end{array}$ & $\begin{array}{c}\text { * Dry River as } \\
\text { limited binding } \\
\text { factor or North and } \\
\text { East Heights area } \\
\text { * Establishment in } \\
\text { the vicinity of one } \\
\text { of the main axes of } \\
\text { outgoing the town } \\
\text { * very appropriate } \\
\text { connect and } \\
\text { situation range or } \\
\text { the town in } \\
\text { presence of main } \\
\text { accesses to it } \\
\text { *Fairly regular } \\
\text { Texture in the } \\
\text { surrounding area } \\
\text { of Vali Asr Square } \\
\text { and the Rahnamaei } \\
\text { street }\end{array}$ & Physical \\
\hline
\end{tabular}




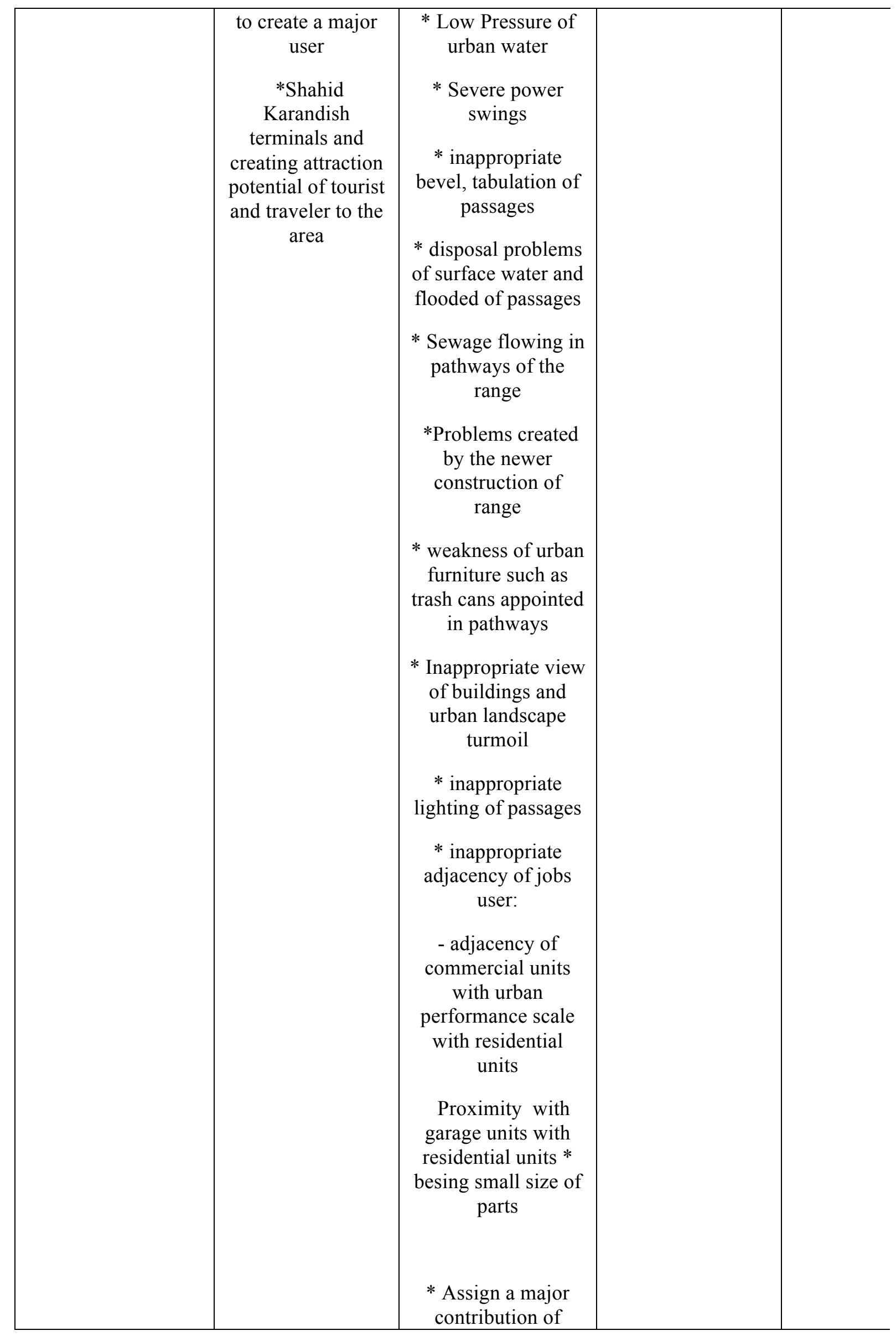




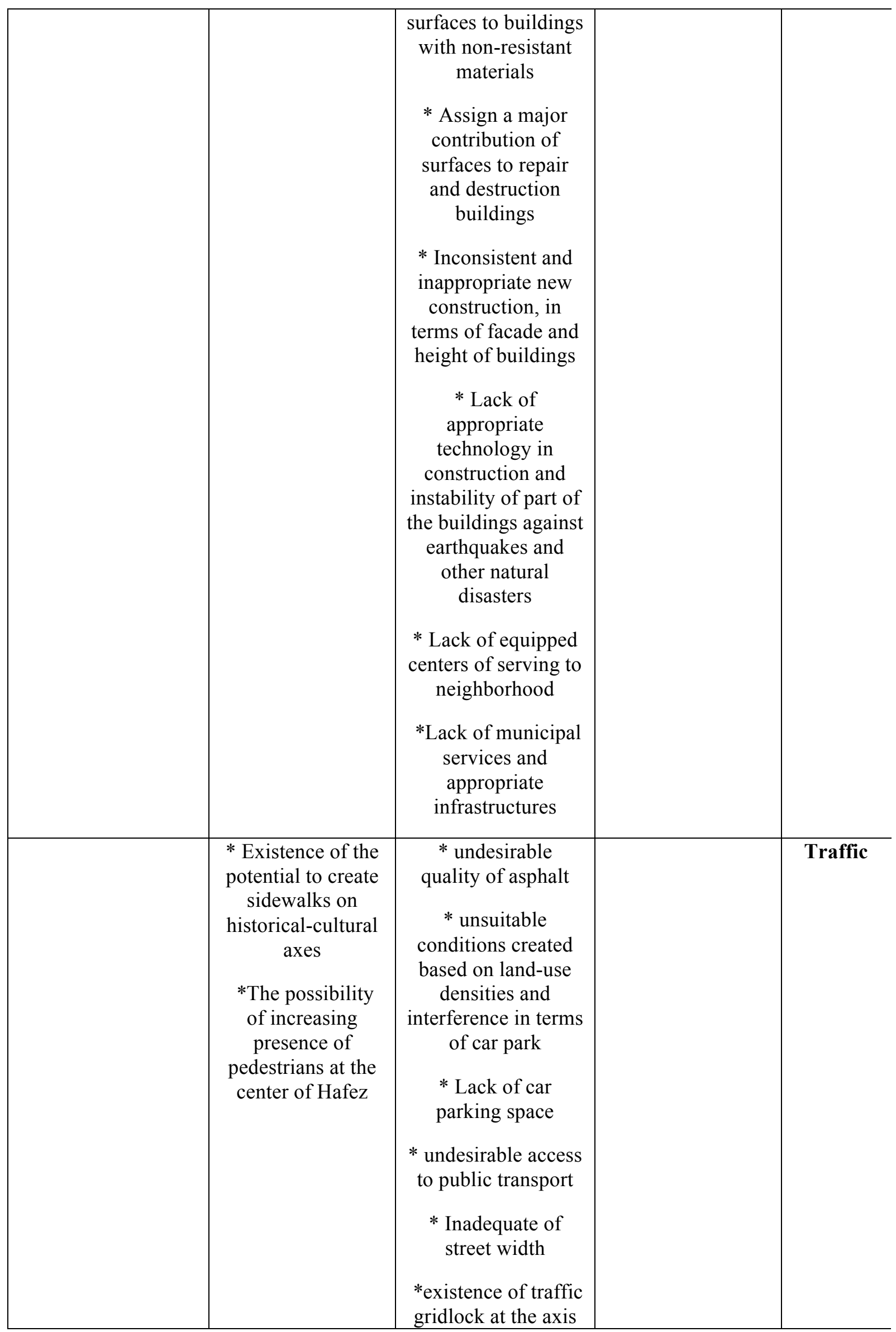




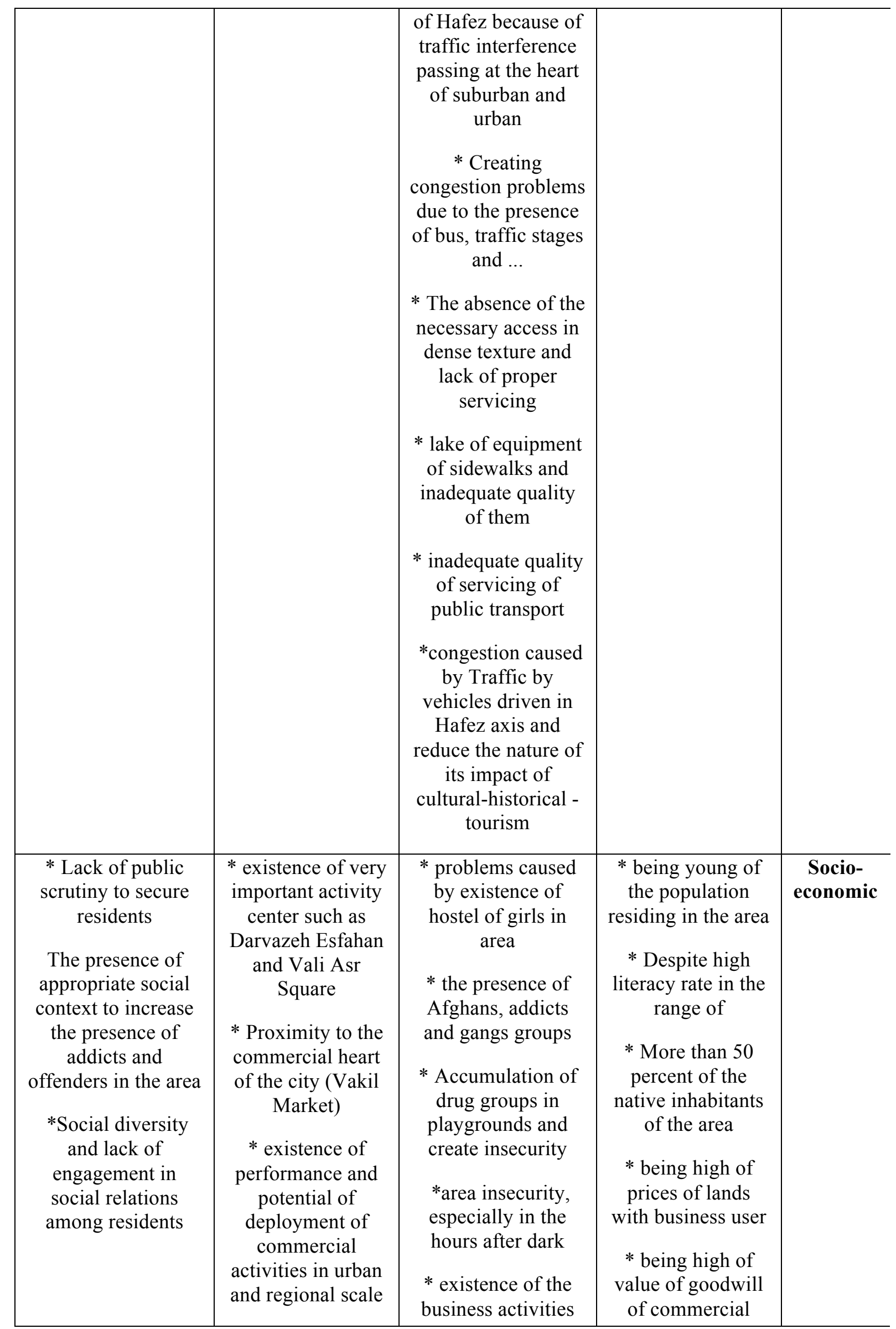




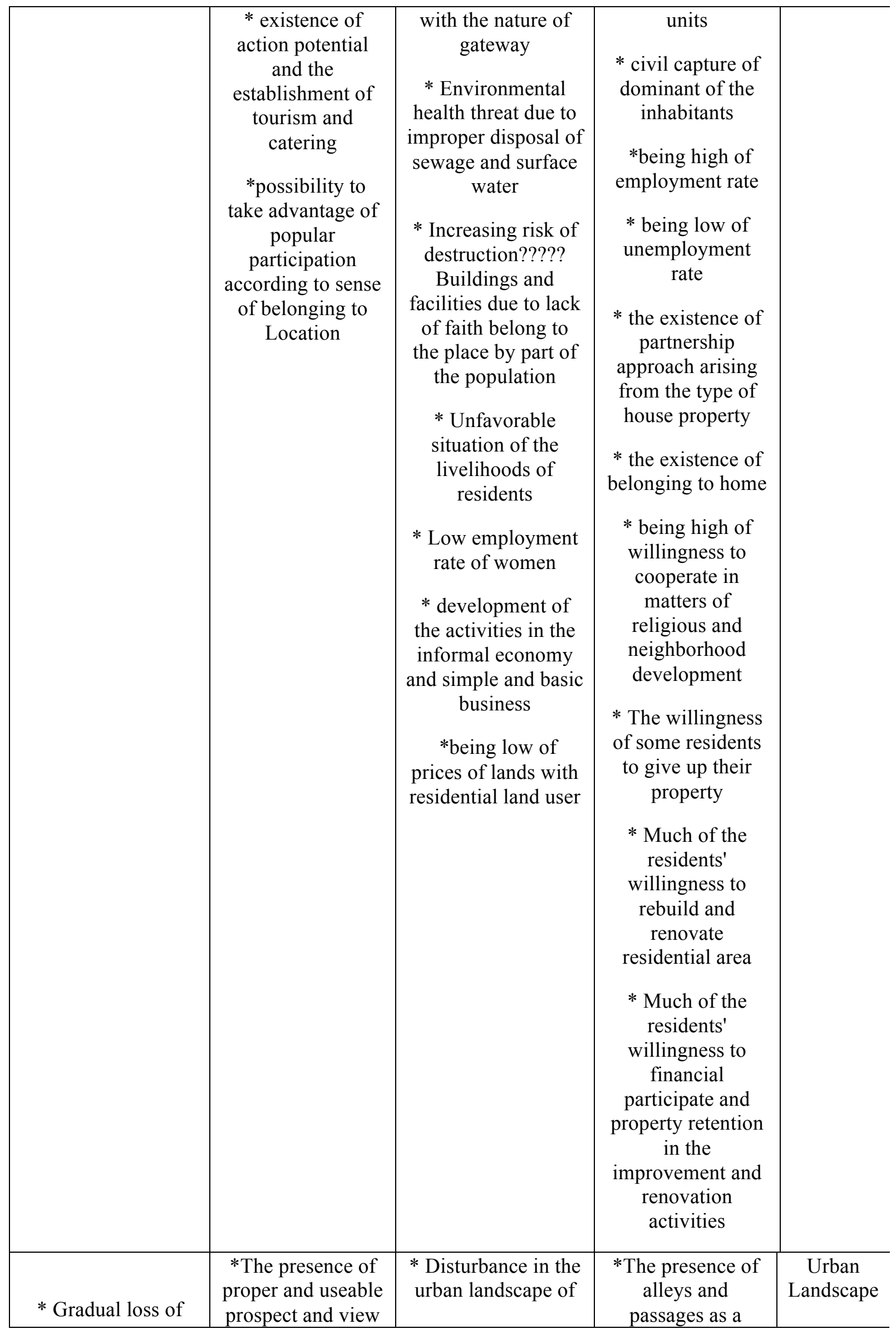




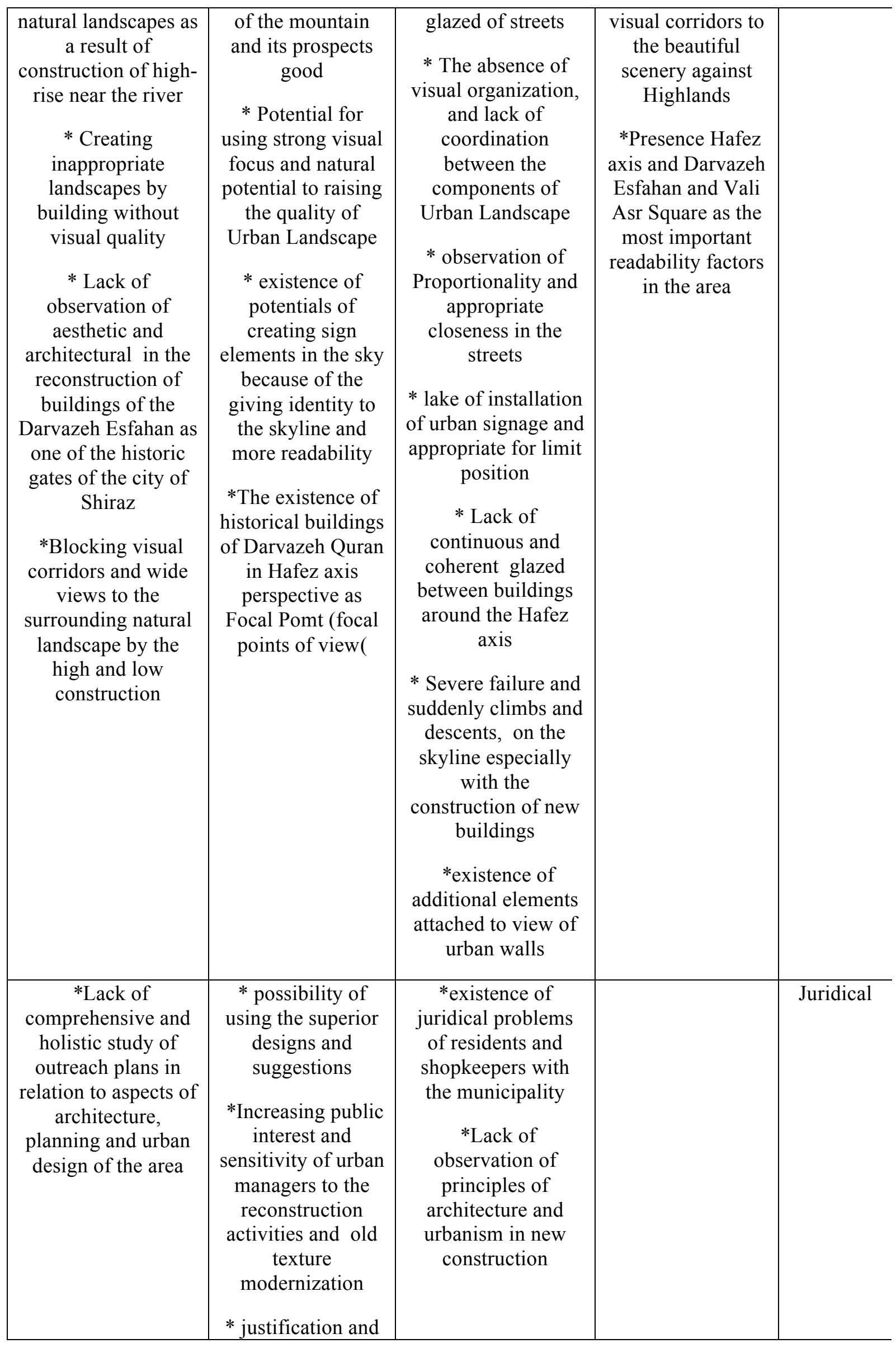




\begin{tabular}{|c|c|c|c|}
\hline & $\begin{array}{c}\text { sensitivity of the } \\
\text { municipal district } \\
3 \\
\text { To the } \\
\text { reorganization and } \\
\text { restructuring of } \\
\text { area }\end{array}$ & & \\
\hline
\end{tabular}

\section{FORMULATION OF OBJECTIVES}

\section{Formulation of macro objectives}

Major objectives have been formulated according to the set of the area features, the way of attitude of superior projects and the way of treatment of urban management system and assemblages and organizations involved in the studied area as follows:

Promotion of cultural - tourism identity of the area in order to play the main role

Promotion of performances level of urban scale and expansion of high activities

Functional - activity balancing of the area in order to promote the quality of life and quantitative and qualitative improvement of residence conditions

Strengthening urban management system by relying on attracting maximum participation of public institutions and economic efficiency of capital

\section{Formulation of micro objectives}

Micro objectives of the projecting form of spatial and visual organization, functional and activity structure, financial system and the way of participation, legal and social system and transportation system have been chosen Based on the posed macro objectives in order to organize, reconstruct and renovate the area. They are provided as follows:

\section{spatial and visual organization of the area}

Hafez spatial, physical and functional-based organization as a connector factor of historical - cultural region to historical - cultural and tourism elements of eastern and northern areas of Shiraz city

Strengthening the spatial relationship between tourist attraction facilities existing in the area, and its adjacent areas with tourism spaces existing in southern, northern, and eastern areas of the area as a connector factor

Providing desirable visual and perceptional quality in creation of urban spaces

Creating facade, sign and altitudinal emphases in line with readability and diversity in perspective of axis of Hafez to Quran gate as one of the city's historical entrances

Strengthening spatial and visual relationship between tourism places, Dry River and northern and eastern highlands of the city

Preserving and organizing corridors of vision to natural landscapes and surrounding highlands

Strengthening the presence of Dry River as a natural landscape

\section{Functional and activity structure}

Functional refining of the area from activities inconsistent and incompatible with the role of area

Development of green spaces equipped in the northern and eastern edge of the area 
Stabilizing the resident population and population loading in form of high communities

Providing suitable public and welfare services in centralization zones and axes in order to meet the needs of residents and referrers

Providing the required land uses and facilities and supportive of cultural - tourism potentials

Private Green spaces development in different land uses

Urban infrastructures network organization and expansion, especially surface water disposal system and sewerage network

Luminal structure design of the effective areas in order to maintain centrality of Hafez Avenue

\section{The way of participation and financial system}

Making-opportunity to attract private capitals in order to provide tourism services

Use of resident participation through applying local forces and attracting small capitals and obtaining financial credits and facilities in order to carry out public projects

Provision of facilities to encourage private sector investors to accelerate formation of complementary activities

Use of managerial tool and facilities of the governmental and public sector besides private sector and public participation

\section{Social system}

Increase the level of social interactions and treatments among people and people with officials

Increasing employment opportunities level for residents due to the creation of new and large-scale land uses

Formulating regulations and criteria of construction and building facade fits with the role and identity of the area

\section{TRANSPORTATION SYSTEM}

Reforming hierarchy functional system of the network

Creating and strengthening pedestrian axes according to the existence of attracting tourism pillars

Functional refining of traffic and organizing suburban traffic in the axis of Hafez

Increasing parking power capacity in the area according to the future needs and suggested land uses

\section{SUMMARY}

Development, from inside is one of the characteristics of Iranian cities. The age of the oldest cities of Iran in southwest of the country is 5,000 years. But we do not encounter with a problem as old Texture during the history of Iran country before this recent century. Changes resulting from globalization of the economy and culture affected social relations and consequently spatial relations.

Accordingly, coherent relation of urban elements collapsed and old Textures lost their position against new Textures and turned into stagnation. Destruction process of urban old Textures continues despite the provision of different improvement and renovation projects. This is because of various reasons, including managerial structure, absence of specific pattern, mere emphasis on physical dimensions, Local and sectional dealing with worn Textures and so on.

Undesirability of social, economic, physical indices in the studied area can be realized by evaluating these indices and comparing them with Shiraz city average and urbanization standards. Negative 
population growth, high unemployment rate, low income of the household head, high percentage of illiteracy of headed households, residents of the region being immigrant, being abandoned and dilapidated and erosion of residential units, shortage of service-welfare land uses, and their undesirable distribution in the tissue, existence of incompatible land uses, low width of passages, and so on all imply the stagnation of the area in terms of sustainable urban development indices. Therefore, comprehensive, long-term and completely systematic policies in order to achieve sustainable development of the studied worn Texture are one of the important necessities. We suggested three strategies of "urban endogenous development", "empowerment" and "land uses organization" in this regard.

This pattern is in a continuous and coherent process see social, economic, cultural, demographic and physical issues together and for each other. It tries to provide a comprehensive and integrated program to organize worn tissues. Experience has shown that the primary methods and one-dimensional and unilateral programs while not removing the problems, but also they have caused a serious trouble in urban life system of the tissue.

So attention to various aspects and the topic and comprehensive and coherent planning based on components of economic, social, cultural, managerial, physical and so on at the scale of the neighborhood and the city ensures sustainable development of the studied worn tissue.

\section{SUGGESTIONS}

- $\quad$ The scope of cities' development to be closed and / or limited and the encouraging density for worn Textures to be defined to increase price of intramural worn lands. This is because if the urban area is open and the city is able to be expanded, in this case intramural lands price, specially worn Texture does not raise much. This is a risk that threatens investment in worn tissues.

Organizing and improving the situation of worn Textures can be done by reforming the region spatial organization through reforming accesses network, reforming land uses incompatibility, and removing troublesome land uses or change the type of land uses and transferring travel-making land uses to other urban areas.

- Many commercial and administrative lands and so on in this region apply their influence at suburban extent. They are the origin of travel-making from other regions to the central part of the city. This process while creating heavy traffic, increases air and noise pollution and thus reduces the quality of life in the region.

emoval of this problem needs to transfer some land users, such as market to marginalized regions. The amount of demand for administrative, educational travel and so on to the region can be also reduced by the use of information technology and realization of e-government. And the excess land uses in the region can be changed gradually.

- $\quad$ Regional and zonal centers to be defined in new textures around the cities. The developments around cities merely with residential land use to be avoided. Intermixture of different land uses in new textures can reduce the amount of travels and the pressure on central texture. It can enhance the quality of life in old textures of cities and promote the tendency to live in the central textures of the cities.

- $\quad$ Organization of worn textures should be supported through planning policies and financing of the government and / or municipality. This is because the returns rate of these projects is low and investment risk is high. These two features makes local governments and states intervene in construction process of urban worn textures and support these projects by paying subsidies and granting credits.

In addition, global experience suggests also a kind of work organization and use of cooperative methods (residents' joint cooperative, financial suppliers, and local authorities) to develop construction in urban worn textures. This type of organization should be also experienced in our country.

Process of planning and management of urban worn textures in Iran must take place based on participatory approach. This pattern is based on maximum public participation in the planning process 
and implementation of renovation operations and reduction of the role of urban management institution (municipality) to provide software policies, supply infrastructural affairs, direct financial and technical facilities, and as much as possible to avoid hardware activities in implementation of the projects.

Early residents being stayed in the place, and preventing the movement of families to the periphery, undesirable spatial consequences of implementation of the project, such as poverty and informal settling in cities, preventing social texture disintegration and dispersion of the early residents due to neighborly and ethnic relations in these neighborhoods, benefiting the residents of these neighborhoods of the added value resulting from the implementation of renovation projects, providing the required financial resources through attracting public capitals in order to guarantee the implementation of renovation projects, and increasing supervision power of urban management to accelerate urban worn textures renovation activities in the country are of the objectives of the suggested pattern.

- $\quad$ Residents having privileges such as exemption from toll related to license to build and finish building from the municipality, the right of free split of municipal installation such as water, electricity, gas, phone, having registered and legal facilities related to property, reduction of administrative stages of construction and granting banking facilities with appropriate time of repayment and interest, applying supervision and provision of technical services to residents through existing civil institutions, such as engineering system organization, technical and executive consultants, provision of residents' temporary settling cost during the implementation of the project, and so on can be effective in developing public participation in implementation of the project.

A single, strong, and participatory management in the local arena to be created in order to implement the project and carry out the necessary actions in this regard. Old texture municipality has been established in some countries in this regard. This institution direct and manage all actions conducted in these textures.

We encounter with managerial competition and plurality of managerial institutions in our country. Establishment of municipalities specific for these textures will not solve the problem of departmental and thematic management governing over urban management system of these textures. We in fact add another parallel organization to the country urban management system by this action.

To prevent serious damage to the social and physical worn textures, limited and gradual intervention policy will be used instead of massive and sudden physical intervention in organizing them.

- Creation of traffic area in the central area of Shiraz city and establishment of numerous parking at the four corners of the central texture of the city in order to reduce traffic and bustle of the streets leading to this region.

- $\quad$ The role of people and participation of citizens in decision-making process and decisionmaking process had been pale. Public opinions and the actual residents of the texture are not observed in most of organization projects. The experiences of the last two decades suggest that the best projects will not succeed without the presence and participation of the people.

So defining a mechanism for effective participation of the people in the preparation and execution of improvement and renovation projects are considered of the important necessaries.

Urban endogenous development strategy must be as victorious discipline- making strategy in a sustainable form to achieve Shiraz sustainable development. This while protecting the environment, prevents excessive expansion of the city and reduces the travel volume at the level of regions and neighborhoods.

Accessing such sustainability needs lands use planning based on pedestrian access as well as adding services in the whole city. Optimal use of intramural spaces, wastelands, dilapidated, abandoned and 
worn, moderate increase in building density are considered of fundamental strategies to achieve pattern of "urban endogenous development" of worn tissue.

Urban endogenous development pattern with an emphasis on inner expansion of the city, the use of appropriate density and wasteland is the most appropriate expansion pattern particularly for cities that are with low density. This theory creates safer and more dynamic urban areas by intensifying land uses. It provides the possibility to support local businesses and services, greater social justice, and social interaction and thus more attention to facilities.

Quality of life indices (access to facilities, reduction of travel, health, and social interaction, etc...) and energy consumption from economical dimension and the environment are observed optimally.

Attention to sustainable development of the Texture through the revival of physical-spatial identity and architectural values of the tissue, lack of unilateral emphasis on maintaining old buildings and works individually, and ignoring dimensions of their association with living situation, public spaces and culture of the people around it. This is because urban sustainability is possible by maintaining culture and history of the city, social cohesion, not with mere emphasis on physical improvement.

- The policy of minimum intervention of government and municipalities in the body of neighborhoods and buildings and minimum displacement of the residents of these areas, following extensive interventions that lead to social and economic disintegration of the neighborhoods and widespread displacement of their residents to be strictly avoided as possible in improvement and renovation programs of urban worn areas. This policy does not mean preventing increase of density, destruction, and renovation by the owners in worn areas.

- $\quad$ Re-integration and re-differentiation of registered plaques program in small blocks scale with maintaining local community interests to be implemented If needed, and priority to be given to integration of parts by the owners and / or by minor manufacturers' participation to solve the problem of micro-lithic and create the motivation of reconstruction.

- Urban worn areas and neighborhoods renovation services offices hold educational workshops by collaboration of the municipality to develop the local economy and empowerment of resident communities.

- $\quad$ Provision of educational, health, care, installation, sport, recreational and cultural services at the extent of the averages existing in the city and standards to increase the quality of life and improve socio-economic status of the residents of worn tissues.

So the first step in this regard is that the municipality as responsible system for this affair should create a municipal branch of renovation organization, which is representatives of municipality about urban worn texture in the area of the intended texture; so that this institution has all the legal authorities of the municipality and receives its power from it.

This organization will have a performance almost similar to regional civil organizations. Therefore, the executive institution entitled "civil and renovation organization of the neighborhood" within the geographical area of the neighborhood (region) will be created. The duties of this institution are of software type and will have the domain of management, guidance, supervision and control of implementation of renovation and improvement projects.

Decision-makers throughout the country for setting up such a base (establishment of representatives of institutions involved in the renovation affair in renovation organization of the neighborhood); in addition, they are part of the cabinet, Tehran's City Islamic Council and part of the judicature. They can make themselves obligated for superior executive cooperation and coordination implementation in the form of a time agreement of their subset institutions by superintendence of the region civil organization for effective communication of this organization with the people. Geographical Councils of the neighborhoods are suggested to be formed 
The duty of this council is to identify the needs and priorities of the neighborhood residents through communication and conferring with them and direct budgets towards the neighborhood renovation priorities.

nother council entitled Thematic Council of the neighborhood is also suggested about setting different policies on renovation. This council is of the various stakeholders such as investors, professionals of the building, manufacturers and distributors of materials and NGOs. Its duty is to set fiscal and executive policies of renovation based on the priorities determined by the Geographical Council of the neighborhood.

Residents located in urban worn Textures and other stakeholders will pose their demands and requisitions through these two institutions. They will participate in making decisions, making policies and programs related to their living environment.

\section{REFERENCES}

Asayesh, H. (2002); principles and methods of rural planning, Payam Noor University Press, Fifth Edition Bahrain, Hussain, 1376; urban planning and sustainable development approach Journal, No. XVII.

Ashori, D. (1996); the legacy of modernity, tradition, modernity, postmodern, Publications Cultural Institute path.

Aghai. Leila; Bandali,Maryam and Rezai (2007); laws and regulations in the management of urban distressed areas (zone 15 and 17 of Tehran Municipality), the first congress of old urban tissue, the prospect of sustainable development, values and challenges, pp. 9-1.

Ebrahimzadeh Assemin, Hossein and Ebrahimzadeh, Eisa (2010); An Analysis of spiral growth factors, and physical development of the city of Tabas after the earthquake using entropy model Holdren, 25 Geography and Development, Number 19, Fall, pp. 46 -25.

Ablaghi, A. (2001): historical context, conservation, restoration, rehabilitation or renovation, Journal of Seven Cities, Issue 4.

Ahadnejad, M. and Meshkini, A. (2007); the impact of urban land supply policies in the process of expanding the exhaustion of old towns (case study area a) First Conference of the urban distressed areas, the prospects for sustainable development, values and challenges, Pages 39-31.

Astratosfki, Vatslaf (1992); contemporary urban development, translation Laden E'tezadi, Tehran University Press

Esmaeil Pour, M., N (2010), check the status of housing in informal settlements and providing regulatory strategies Case study: Yazd Hassan Abad district, urban and regional research, the first year of the fourth number, Spring, pp. 112-95.

Akbari, A. (2007); a new approach in the rehabilitation and recovery of old residential areas, the first conference on urban distressed areas, the prospects for sustainable development, values and challenges, pp. 91-82.

Aman Pour, S. (2007); the master plan for housing and urban distressed areas of the country's 1386 budget, the first conference on urban distressed areas, the prospects for sustainable development, values and challenges, pp. 99-92.

Amin Zadeh, B. (2009); increased density in older tissues, paper construction.

Izadi, Mohammad Saeed, an analysis of the course of development efforts and improvement of the urban fabric of the start date, issue number 7 Development Corporation and Urban Upgrading, Ministry of Housing and Urban Development.

Bagheri, Ashraf Sadat (2007); review historical evolution rehabilitation and renovation of old ones in Iran, the first conference on urban distressed areas, the prospects for sustainable development, values and challenges, pp. 138- 122 .

Bahrain, Sayed Hossein (1999); modernity, Fratjdd and then Urban Development, Tehran University Press

Badri, A. (1990); Rural Center Location, Dissertation for M.A, University of Modares, Tehran, Iran (In Persian) 
Bănică, A., (2010) Sustainable Urban Development Indicators Case Study:

TÂRGU OCNA Town, Present Environment and Sustainable Development, NR. 4, pp. 339-352.

Blowers, A., (1994); Planning for Sustainable Environment, A Report Town and Country Planning Association, London, Ear Thscam

Christopher A. (1979); the Timeless way of Building, New York 